\title{
Modeling the Regional Impacts of Disasters on Economic Growth
}

\author{
Cretson L. Dalmadge \\ Winston-Salem State University
}

This paper utilizes structural equation modelling to analyse the regional impacts of disaster on economic growth. The analysis is conducted at the global level, and repeated for the nations that constitute Europe, Asia, Sub-Saharan Africa, and the Caribbean and Central America. The findings support a relationship between disasters and variations in economic growth. The output of the analysis suggests that disasters account for eleven percent of the variations in GDP globally. When assessed individually, Europe and the Caribbean and Central America have adjusted $R^{2}$ of 0.243 and 0.244, while Asia and Sub-Saharan Africa had impacts of 0.09 and 0.10 , respectively.

Keywords: regional impacts, disasters, economic growth, structural equation modelling

\section{INTRODUCTION}

The relationship between disasters and economic growth is still unfolding. Single disaster analysis largely focused on a single nation or small regional level have found significant relationship between disasters and economic growth. Kellenberg and Morabak (2008) found measurable patterns between losses from natural disaster and economic development. Felbermayr and Gröschl (2014) found that post-disaster growth decreased relative to pre-disaster forecasts. Other studies have found that disasters lead to strong downturn in economic performance especially for smaller nations. Studies on disaster impacts in the Caribbean islands for example have found significant and negative impacts of disaster (Hager et al (2008), Frankfurt (2009)).

While most of this focus has been on the negative impacts of disasters, there is some support for the thesis that disasters are capable of positively impacting economic growth (Guimaraes et al., 1993; Ewing \& Kruse, 2002; Skidmore \& Toya, 2002, and Greenberg et al., 2007). They posit that recovery often demands rebuilding, and these rebuilding projects may lead to modernization that generates improvements in efficiency and productivity. The projects may be spurred by businesses as they address recovery after disasters or by governments as they infuse funds in severely affected communities. The result is that economic growth after disaster has sometimes outpaced growth rates before the disasters (Surowiecki, 2011).

Some work on the macroeconomic impacts of disasters have also gone beyond the local impacts of single disasters. This focus has largely examined the impacts of disasters on supply chain performance. Altay and Ramirez (2010) found that disasters affect global supply chains, and these impacts differ for upstream versus downstream partners. Parker et al (1987) addressed the need to examine forward linking and backward linking activities as the impacts of disasters are assessed. Forward-linked activities address 
the reliance of the broader market for their output and backward-linked rely on broader sources for supply/input.

Kunreuther (1996) addressed the role of insurance in mitigating risks. The direct effects of disasters are usually addressed by insurance. Indirect effects ripple across value chains and are lesser mitigated by insurance and reinsurance process. As such the potential arise for cases where the impacts of a disaster may be significant at the indirect-level even where there is little effect at the direct-level. Further, work on 'economic dependence' addresses the relationship between economic output in one geographic region and activities in another. Dunford and Smith (2000) and Koks and Thissen (2016) suggest that economic output is influenced by activities well outside of the region in question. This suggest that the indirect of disasters in conjunction with economic dependence could potentially spread the impacts of disasters to distance geographic region.

The combination of these issues leaves many unanswered questions and in cases unaddressed issues. First, do disasters in one region affect economic output in other regions? For example, do disasters in the large consumer driven market in North America affect global economic growth differently than disasters in other parts of the world, or do the disasters in production or raw material centric areas of the globe affect economic growth in other regions? Second, given the fact that the rebuilding and modernization process following a disaster serves as a potential driver of positive macroeconomic growth, is there a need to look at the prior year's disaster profile as one examines economic output. A bad disaster year may very well set the basis for immediate downturn followed by rebound in economic growth in the following year(s) as recovery takes roots.

Third, to what extend are the impacts of disasters mediated by other factors such as the economic base of the nations or the nature of their markets. Would an economy with a strong manufacturing base be affected differently than one with a large service base? Are nations largely driven by domestic consumption affected differently than those driven primarily by exports?

\section{RESEARCH MODEL}

Figure 1 presents the theoretical framework for the study. Disasters cause destruction that often results in discontinuity in business operations and disruptions in the lives of their customers. The resulting scenario often have major economic impacts. The discontinuities are not formally modelled here, rather the focus is placed on the disasters themselves, their impact on economic growth and the factors that are deemed capable of mitigating these impacts.

Individual nations serve as the unit of analysis and their disaster and economic data are extracted for the period of the study. Disasters serve as the independent variable in the analysis. Disasters are addressed in terms of their numbers and size. Disasters are also studied in the present year i.e., the focal year with the associated economic data as well as the prior year. Further, disasters are assessed at the local/national level as well as regional level. The regional aggregation facilitates the analysis of potential impacts of disasters in another region on a nation's economic performance.

The literature on disaster impacts identifies several attributes for assessing the size of a disaster. These include economic losses, persons affected, persons killed. Normalized measures of "disaster count" and 'persons affected' were chosen as the representative variable. Each were well reported in the study data (very little missing values) and the two were not heavily correlated with each other. Other variables were dropped for high correlation with either the 'disaster count' or 'persons affected' or for having very high percentages of missing values. 
FIGURE 1

THE DISASTER IMPACT MODEL

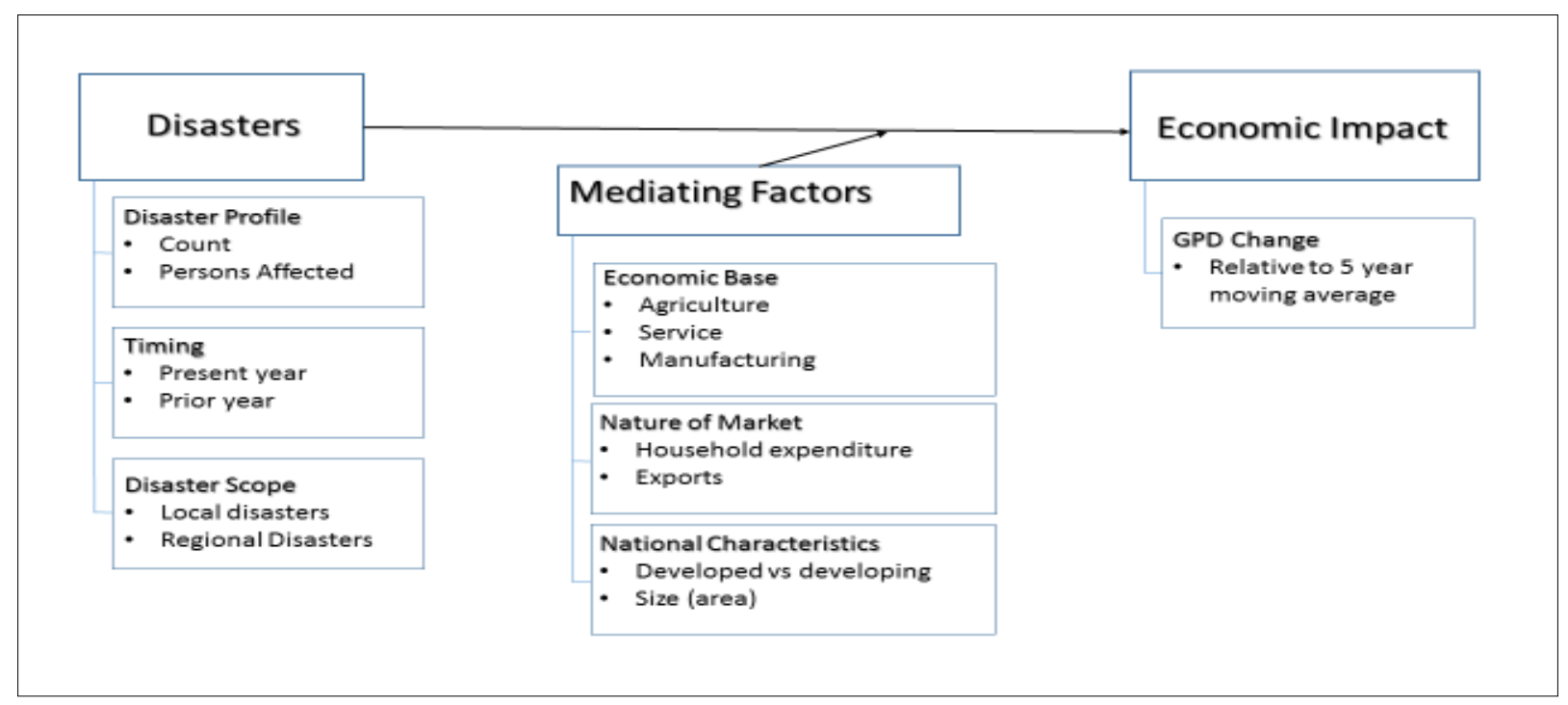

The two chosen variables are also modeled in terms of present year and prior year statistics for each nation. Further, those variables are addressed at the local and regional levels. Disaster counts for example are addressed at present and prior year count for a given nation, and present and prior year count for a given geographic region.

Work on the micro-economic impacts of disasters suggest that there are factors that moderate the impacts of disasters. When businesses suffer downtime because of disasters, the resulting impacts are not always the same. A firm in a very competitive industry is usually affected more so than one in a near monopolistic setting. Further, some research suggest that manufacturing firms are affected differently than service-based firms. The model here addresses whether there are factors that moderate the macro-economic impacts of disasters. Would a high level of services in the economic makeup of the country lead to a different pattern of outcomes than those of nations with high percentage of manufacturing or agriculture in their economic base?

Two other moderating variables are examined. First, are the impacts of disasters moderated by the nature of the national marketplaces? Would a nation largely driven by domestic consumption be affected differently than one that is more export focused? Secondly, are there national characteristics that influence the relationship? Are smaller nations affected differently than larger nations and are developing nations affected differently than developed nations.

Finally, the dependent variable, economic impact, is modelled as the change in real gross domestic product (GDP). The five-year moving average of each nations GDP is calculated. GDP variance is than calculated by examining the difference between present year's real GDP and the moving average.

\section{DATA AND METHODOLOGY}

Data is drawn from two sources. First, the global database on disasters EM-DAT is utilized for information on the disasters. Data is utilized for the period 1990 to 2010. This included data on the disaster counts and on the number of persons affected. Other data points, for example the economic loss and persons killed were also collected and utilized in earlier runs of the analysis. Their impacts had little or no additional explanatory value and in many cases were highly correlated with these two primary data points. As such they were excluded from final analysis. 
The second data source is the World Bank's World Development Indicators (WDI). Real GDP along with the necessary data points to generate the agricultural, service and industrialization levels in each nation are extracted for the study period. Data is also extracted on the levels of household spending and export for each nation. In order to provide the necessary five-year moving average, GDP data is collected for five years prior to the study period in addition to the 1990 to 2010 period. All other data points are 1990 to 2010. Population data is also generated from the WDI data.

The disaster data is normalized based on standard convention established in the literature. Disaster counts are normalized as counts per 100,000 persons or counts per 1000 square mile across the literature. Counts were normalized in both ways for the preliminary studies. Counts per 1000 square mile was adopted in the final analysis. 'Persons affected' was normalized as persons per 100,000 residents. The result would be data points of 'Germany disaster count 2000' and 'Germany disaster count 1999' to reflect present and prior year counts, plus 'Germany Affected 2000' and 'Germany Affected 1999' to address the extent to which the local population was affected.

Disaster scope involves calibrating a regional disaster profile to serve alongside the local disaster profile. This facilitates the aspect of the analysis that focuses on whether nations are affected by disasters outside of their national borders or are the economic impacts solely affected by local disasters. The chosen disaster data points ('disaster counts' and 'persons affected') are aggregated for eight major geographic regions (Europe, North America, South America, Sub Saharan Africa, Middle East \& North Africa, Australia and Oceania, Asia, and the Caribbean \& Central America). This is also done for present and prior year. For example, in the year 2000, North America will have a 'North America Count 2000' and a 'North America count 1999'. There would also be 'North America Affected' for both years. A detailed explanation of the variables is provided in Table 1 .

\section{TABLE 1}

\section{THE FULL LIST OF VARIABLES}

\begin{tabular}{|l|l|c|}
\hline \multicolumn{1}{|c|}{ Abbreviation } & \multicolumn{1}{|c|}{ Variable Description } & Level \\
CountryYear & $\begin{array}{l}\text { Unique identifier: each country for each year of the study (e.g., France } \\
\text { 2001) }\end{array}$ & \\
\hline Country & Each nation with strong data representation in both datasets. \\
Region & $\begin{array}{l}\text { Major global geographic regions: N. America, S. America, Europe, } \\
\text { Asia, Caribbean \& Central America, Australia \& Oceania, Middle East } \\
\text { \& North Africa, Sub-Saharan Africa }\end{array}$ & \\
\hline Year & Each of the years 1990 - 2010 & \\
\hline RegionYear & Each region by years of the study (e.g. Europe 2001) & \\
\hline Agriculture & Percentage of Agriculture in the Nation's GDP Output & Country \\
\hline Industrialization & Percentage of Industrial/Manufacturing in the Nation's GDP Output & Country \\
\hline Services & Percentage of Services in the Nation's GDP Output & Country \\
\hline Count & Number of disasters per square mile (for each nation) & Country \\
\hline Affected & Persons affected per 100,000 population (for each nation) & Country \\
\hline Pr.Count & Number of disasters per square mile (for each nation) in prior year & Country \\
\hline Pr.Affected & Persons affected per 100,000 population (for each nation) in prior year & Country \\
\hline Asia Count & No of disasters per 1000 square miles in Asia & Regional \\
\hline Asia Affected & Persons affected per 100,000 residents in Asia & Regional \\
\hline Pr-Asia Count & No of disasters per 1000 square miles in Asia in prior year & Regional \\
\hline $\begin{array}{l}\text { Pr-Asia } \\
\text { Affected }\end{array}$ & Persons affected per 100,000 residents in Asia in prior year & Regional \\
\hline
\end{tabular}




\begin{tabular}{|l|l|c|}
\hline \multicolumn{3}{|c|}{ Above 4 variables are packaged for each of the eight geographic regions (listed earlier) } \\
\hline HouseholdExp & Percentage Contribution of Domestic expenditure to GDP & Country \\
\hline Exports & Percentage Contribution of exports to GDP & Country \\
\hline Developed & UN classification of developed vs. developing nation & Country \\
\hline RealGDP & Real GDP (year $=2000$ ) & Country \\
\hline 5YrAvge & 5 year moving average of GDP (does not include present year) & Country \\
\hline GDP-Diff & Difference between real GDP and the prior 5-year average. & Country \\
\hline
\end{tabular}

Table 2 shows the makeup of the factors used in the analysis. The independent and mediating factors are developed as logical groupings of related variables. Local factors, for example, are the local disaster statistics. These are the popularly studied items in disaster impact analysis: normalized measures on 'disaster counts' and 'persons affected' for present and prior years. The two market related data elements, household expenditure and percentage of export in the nations economic output are grouped into a Market factor. 'National Characteristics' incorporated the nations size and it's classification (developed vs developing). Finally, the regional factors aggregate the four local factors at each of the eight geographic regions to form the eight regional factors.

TABLE 2

THE INDEPENDENT AND MEDIATING FACTORS

\begin{tabular}{|c|c|c|c|c|c|c|}
\hline Variable & $\begin{array}{l}\text { WarpPLS } \\
\text { Abhreviation }\end{array}$ & $\begin{array}{c}\text { Number } \\
\text { of }\end{array}$ & \multicolumn{4}{|c|}{ Indicators } \\
\hline Local Disaster & Local & 4 & $\begin{array}{l}\text { Count- } \\
\text { sqMi }\end{array}$ & Affected & $\begin{array}{l}\text { Pr. } \\
\text { Count- } \\
\text { sqMi }\end{array}$ & Pr. Affected \\
\hline $\begin{array}{l}\text { Economic } \\
\text { Base }\end{array}$ & EcoBase & 3 & Agriculture & Industrialization & Services & \\
\hline $\begin{array}{l}\text { Nature of } \\
\text { Market }\end{array}$ & Market & 2 & $\begin{array}{l}\text { Household } \\
\text { expenditure }\end{array}$ & Exports & & \\
\hline $\begin{array}{l}\text { National } \\
\text { Characteristics }\end{array}$ & NatChar & 2 & $\begin{array}{l}\text { Developed } \\
\text { vs } \\
\text { developing }\end{array}$ & Size (area) & & \\
\hline Europe & Europe & 4 & $\begin{array}{l}\text { Europe } \\
\text { Count }\end{array}$ & $\begin{array}{l}\text { Europe } \\
\text { Affected }\end{array}$ & $\begin{array}{l}\text { Pr. } \\
\text { Europe } \\
\text { Count } \\
\end{array}$ & $\begin{array}{l}\text { Pr. Europe } \\
\text { Affected }\end{array}$ \\
\hline $\begin{array}{l}\text { North } \\
\text { America }\end{array}$ & NorthAm & 4 & $\begin{array}{l}\text { NorthAm } \\
\text { Count }\end{array}$ & $\begin{array}{l}\text { NorthAm } \\
\text { Affected }\end{array}$ & $\begin{array}{l}\text { NorthAm } \\
\text { Count }\end{array}$ & $\begin{array}{l}\text { NorthAm } \\
\text { Affected }\end{array}$ \\
\hline $\begin{array}{l}\text { South } \\
\text { America }\end{array}$ & SouthAm & 4 & $\begin{array}{l}\text { SouthAm } \\
\text { Count }\end{array}$ & $\begin{array}{l}\text { SouthAm } \\
\text { Affected }\end{array}$ & $\begin{array}{l}\text { Pr. } \\
\text { SouthAm } \\
\text { Count }\end{array}$ & $\begin{array}{l}\text { Pr. } \\
\text { SouthAm } \\
\text { Affected }\end{array}$ \\
\hline $\begin{array}{l}\text { Sub Saharan } \\
\text { Africa }\end{array}$ & SSA & 4 & $\begin{array}{l}\text { Sub- } \\
\text { Saharan } \\
\text { Africa } \\
\text { Count }\end{array}$ & $\begin{array}{l}\text { Sub-Saharan } \\
\text { Africa Affected }\end{array}$ & $\begin{array}{l}\text { Pr.Sub- } \\
\text { Saharan } \\
\text { Africa } \\
\text { Count }\end{array}$ & $\begin{array}{l}\text { Pr.Sub- } \\
\text { Saharan } \\
\text { Africa } \\
\text { Affected }\end{array}$ \\
\hline $\begin{array}{l}\text { Middle East \& } \\
\text { North Africa }\end{array}$ & ME-NAfr & 4 & $\begin{array}{l}\text { ME-NAfr } \\
\text { Count }\end{array}$ & $\begin{array}{l}\text { ME-NAfr } \\
\text { Affected }\end{array}$ & $\begin{array}{l}\text { Pr. ME- } \\
\text { NAfr } \\
\text { Count }\end{array}$ & $\begin{array}{l}\text { Pr. ME- } \\
\text { NAfr } \\
\text { Affected }\end{array}$ \\
\hline
\end{tabular}




\begin{tabular}{|c|c|c|c|c|c|c|}
\hline $\begin{array}{l}\text { Australia and } \\
\text { Oceania }\end{array}$ & Oceanic & 4 & $\begin{array}{l}\text { Oceania } \\
\text { Count }\end{array}$ & $\begin{array}{l}\text { Oceania } \\
\text { Affected }\end{array}$ & $\begin{array}{l}\text { Pr. } \\
\text { Oceania } \\
\text { Count }\end{array}$ & $\begin{array}{l}\text { Pr. Oceania } \\
\text { Affected }\end{array}$ \\
\hline Asia & Asia & 4 & Asia Count & Asia Affected & $\begin{array}{l}\text { Pr. Asia } \\
\text { Count }\end{array}$ & $\begin{array}{l}\text { Pr. Asia } \\
\text { Affected }\end{array}$ \\
\hline $\begin{array}{l}\text { Caribbean \& } \\
\text { Central } \\
\text { America }\end{array}$ & Carib & 4 & $\begin{array}{l}\text { Carib } \\
\text { Count }\end{array}$ & Carib Affected & $\begin{array}{l}\text { Pr. Carib } \\
\text { Count }\end{array}$ & $\begin{array}{l}\text { Pr. Carib } \\
\text { Affected }\end{array}$ \\
\hline
\end{tabular}

* All Counts and Persons-Affected are normalized (as discusses above)

'Warp PLS' was utilized to run the structural equation models. The software allowed for modeling of the mediating effects. As is customary with structural equation modeling, preliminary runs of the model are conducted and variables with little or no contributory values are eliminated.

The final run of the global analysis utilized the full data set i.e., all country-year data points and associated data. The regionally focused analysis utilizes only the country-year data for the countries within those regions. For example, the European analysis addresses disaster impacts for only European nations for the years in the analysis. It however incorporated regional disaster summary from each of the eight geographic regions as independent variables. As such, the model output shows whether disasters in North America or Asia for example will affect variations in GDP in the European nations.

\section{RESULTS}

Figure 2 and Tables 3 and 4 show the output for the global model. Figure 2 is a screen shot of the output for the global analysis. The relative strengths of each independent variable in the model and their impact on the variance in GDP growth can be seen. The output shows both the $\beta$-values and the level of significance (p-values) of each factor. Several of the variables were excluded after the preliminary runs because of high p-values. The impacts of the mediating variables are also shown. First, the national characteristics was removed from the analysis. Second, 'Market Characteristics' were used as a mediating variable - but only for the impacts of local disasters on the variance in GDP growth. Third, while many of the $\beta$-values were low, 'Economic Base' contributed to the quality of the model in its originally conceptualized form. That is, it moderated all the independent to dependent variable relationships. 
FIGURE 2

OUTPUT OF THE GLOBAL ANALYSIS (ALL NATIONS - SCREEN SHOT)

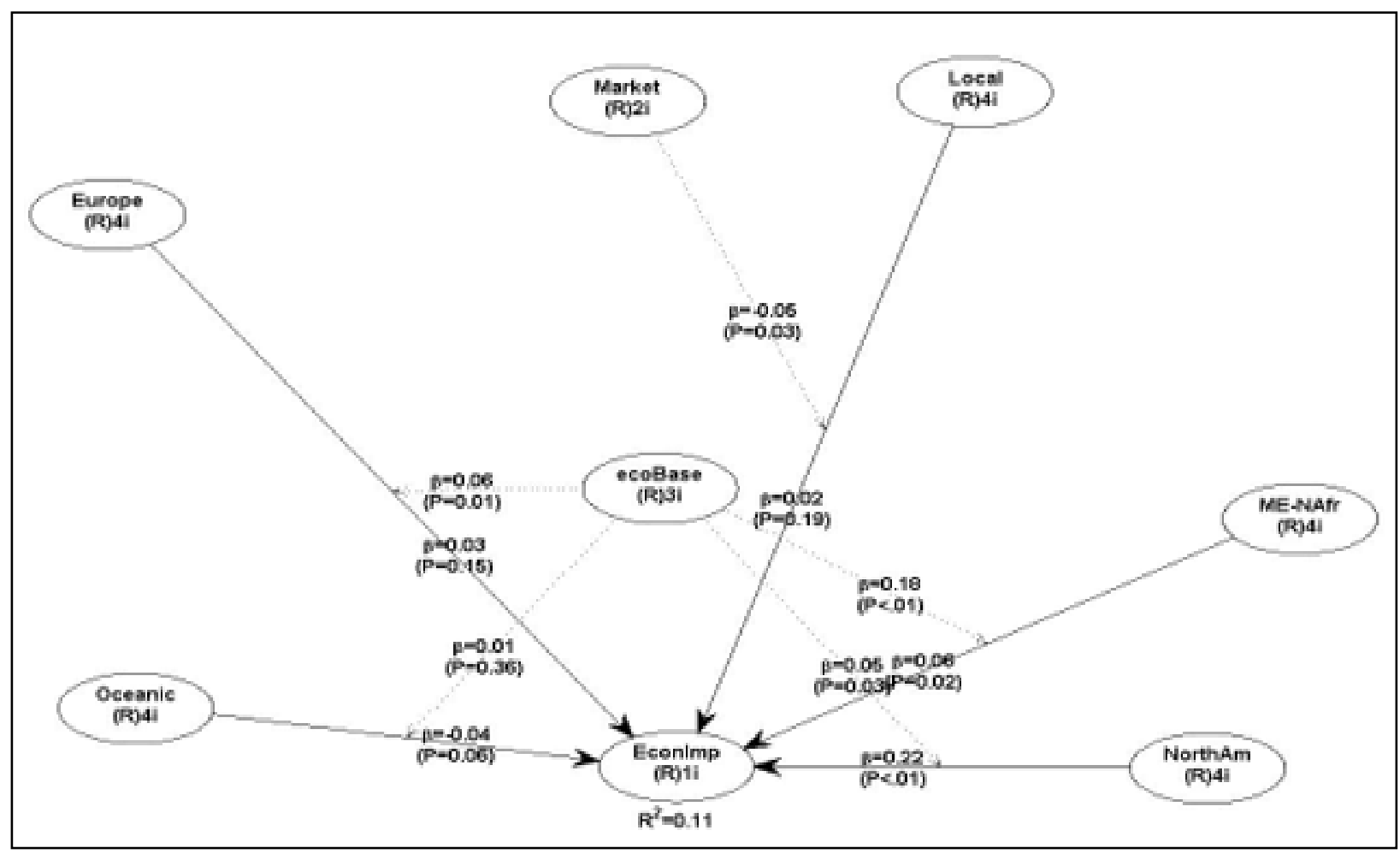

The $\beta$-values and p-values from figure 2 are extracted and displayed in Table 3. There are no contributions from Asia, South America, Central America and the Caribbean, and Sub-Saharan Africa. Those four regional factors were dropped after the preliminary runs. The final run utilized the 'local disaster' in conjunction with the regional factors for North America, Middle East and North Africa, Europe, and Australia and Oceanic. This modeling inclusive of the mediating impacts generated the highest quality output.

The final model has an adjusted $R^{2}$ of 0.11 and a $\mathrm{p}<0.001$. That is, the disaster model explains eleven percent of the variance in GDP growth relative to the five-year moving average. While this is not an extremely large percentage, it suggests that disasters do contribute to the economic performance of nations. Also, given the range of monetary policies that are implemented to manage economic performance, eleven percent becomes a noteworthy contribution.

North American disasters has the most pronounced effects, among the independent factors. It has a $\beta$ value of 0.22 with $\mathrm{p}<0.01$. Also significant is the 'Middle East \& North Africa' factor. It however has a much lower $\beta$-value of 0.08 . The oceanic disaster factor with its $p$-value of 0.06 sits just above the target range and Europe has a p-value of 0.15 . It is noteworthy that the local disasters have a low $\beta$-value of 0.02 with a p-value of 0.19 . They did not have a significant impact on the economic performance. 
TABLE 3

LOCAL AND REGIONAL INDEPENDENT FACTOR LOADINGS

\begin{tabular}{|l|c|c|}
\hline \multicolumn{1}{|c|}{ Factors } & $\boldsymbol{\beta}$-values & p-values \\
\hline Local Disaster & 0.02 & 0.19 \\
\hline Disasters in Europe & 0.03 & 0.15 \\
\hline Disasters in North America & 0.22 & 0.01 \\
\hline Disasters in Middle East \& North Africa & 0.08 & 0.02 \\
\hline Disasters in Australia and Oceania & 0.04 & 0.06 \\
\hline
\end{tabular}

TABLE 4

SUMMARY OUTPUT FOR THE GLOBAL ANALYSIS

\begin{tabular}{|l|l|}
\hline \multicolumn{1}{|c|}{ Model fit and quality indices } & \multicolumn{1}{c|}{ Acceptable Range } \\
\hline Average path coefficient (APC) $=0.072, \mathrm{P}=0.002$ & \\
\hline Average R-squared (ARS) $=0.110, \mathrm{P}<0.001$ & \\
\hline Average adjusted R-squared (AARS) $=0.104, \mathrm{P}<0.001$ & acceptable if $<=5$, ideally $<=3.3$ \\
\hline Average block VIF (AVIF) $=1.164$ & acceptable if $<=5$, ideally $<=3.3$ \\
\hline Average full collinearity VIF (AFVIF) $=1.209$ & small $>=0.1$, medium $>=0.25$, large $>=$ \\
\hline & 0.36 \\
\hline Tenenhaus GoF $(\mathrm{GoF})=0.216$ & acceptable if $>=0.7$, ideally $=1$ \\
\hline Sympson's paradox ratio (SPR $)=0.900$ & acceptable if $>=0.9$, ideally $=1$ \\
\hline R-squared contribution ratio (RSCR $)=0.800$ & acceptable if $>=0.7$ \\
\hline Statistical suppression ratio (SSR $=0.800$ & \\
\hline $\begin{array}{l}\text { Nonlinear bivariate causality direction ratio } \\
\text { (NLBCDR) }=0.7\end{array}$ & acceptable if $>=0.7$ \\
\hline
\end{tabular}

Table 4 shows the quality metrics as specified by the software (WarpPLS). The first column shows the model output. The second column shows the acceptable range of outputs. As seen in the table, the model outputs were within specification for all data points.

The regional runs of the analysis each generated output similar to the screen shot in Figure 2 and the model fit details in Table 3 and 4. The details are shown in Appendix A. A summary of the $\beta$-values and pvalues for the regional analyses is presented in Table 5. The European model (i.e., narrowing the analysis to European nations only) had an adjusted R-squared of 0.243 with $\mathrm{p}<0.001$. The Caribbean and Central American model had adjusted R-squared of 0.244 with $\mathrm{p}<0.001$. Both regions show a stronger relationship between disaster and economic growth than the broader global community. Asia and Sub-Saharan Africa had adjusted R-squared of 0.089 and 0.096, respectively. Each was significant at $\mathrm{p}<0.05$ level.

TABLE 5

SUMMARY OF THE REGIONAL MODEL OUTPUTS

\begin{tabular}{|l|c|c|c|c|}
\hline \multicolumn{1}{|c|}{ Regions } & R-squared & P & $\begin{array}{c}\text { Adjusted R- } \\
\text { squared }\end{array}$ & P \\
\hline World (all nations) & 0.11 & $<0.001$ & 0.104 & $<0.001$ \\
\hline Europe & 0.259 & $<0.001$ & 0.243 & $<0.001$ \\
\hline Asia & 0.102 & 0.03 & 0.089 & 0.043 \\
\hline Caribbean and Central America & 0.281 & $<0.001$ & 0.244 & $<0.001$ \\
\hline Sub-Saharan Africa & 0.11 & 0.007 & 0.096 & 0.014 \\
\hline
\end{tabular}


A regional run was not performed for North America. With only 3 nations, there were too few data points to support the analysis. The other three regions (South America, Oceania, and Middle East \& North Africa) had marginal number of data points. Their regional models are not reported here.

\section{DISCUSSION}

The findings support Dunford and Smith (2000) view that forces outside the region in question affect the relationship between disasters and macroeconomic performance. Specifically, the results suggest that disasters in other regions or nations affect macroeconomic performance even more so than disasters local to the nation do. Kunreuther's (1996) work on the ability of insurance and co-insurance to alleviate the direct effects of disaster also lends support here. Local disasters usually result in insurance payouts that offset much of the immediate impacts of the disaster. Disasters in other nations are often capable of causing significant disruptions in local value chains but rarely generate significant payouts that could offset economic loss.

As shown in Figure 2, disasters in the large North American consumer market have significant impact on the economic output in other nations. The result is significant at $\mathrm{p}<0.01$ level and has a large $\beta$ coefficient $(\beta=0.22)$. Disaster in the Middle East and North Africa also have a significant impact on global economic performance. However, the $\beta$ coefficient is much smaller than North America indicating a lesser overall impact. European disasters were not deemed significant.

Regional analyses were performed to see whether the geopolitical regions are affected similarly, or do they experience unique dynamics that average or even offset each other when pooled together for a global analysis. While the global analysis generated an adjusted $R^{2}$ of 0.11 , the regional analysis for Europe and the Caribbean generated adjusted $R^{2}$ of 0.243 and 0.244 , respectively. These two regions are each affected at a much higher level than the global dynamic and much greater than the other regions in the study. Numerous studies have addressed the unique vulnerabilities of the small Caribbean islands (Charvériat (2000), Collymore (2011), Frankfurt (2009), Hager et al (2008), Henderson (2004), Rasmussen (2004)). Their small to moderate geographic size and modest economic standing often leaves them especially vulnerable to disasters. Much less focus has been placed on the impacts of disasters on European nations.

It is also noteworthy that Europe is heavily affected by the disasters in both North America and Asia (see Figure 3, Table 6 in Appendix A). North American and Asian disasters are both significant at the $\mathrm{p}<$ 0.01 level, with $\beta$ values of 0.32 and 0.18 , respectively. The economic base (proportion of services, manufacturing, and agriculture) also emerged as a significant mediating variable. For the Caribbean and Central American regionally focused analysis, the disaster situation in North America and South America are both significant and each with strong $\beta$ values (of 0.36 and 0.19 respectively). The economic base of the islands also mediates the relationship with local disasters but is not significant in mediating the relationships with regional disasters (see Figure 4, Table 7 in Appendix A).

The other two regions studied (Asia and Sub-Saharan Africa) have average adjusted $R^{2}$ of 0.10 and 0.11 , respectively. While these are much closer to the global average, the nature of the relationships is quite different. The economic performances of Asian nations are impacted by disasters in North America, Oceana, and other Asian nations. Other variables were eliminated from the analysis because of their low contributions. These three were each significant with $\beta$ values of $0.22,0.13$ and 0.12 , respectively. SubSaharan African nations were impacted by disasters in North America, Caribbean and Central America, and other African nations. These were all significant, with $\beta$ values of $0.20,0.11$ and 0.20 , respectively. Again, local disasters were not significant and fell out of the final optimal model.

\section{CONCLUSION}

Evidence from the global analysis and the four regional analysis all support the thesis that disasters affect economic performance. Further the analyses show that the relationships are not identical. There are however some key commonalities. Firstly, disasters within the nation in question was not significant in any of the five models. That supports the position that indirect impacts of distanced disasters are more likely to 
impact economic performance than local disasters do. Secondly, disaster in the large consumer market in North America affected all regions as well as the greater global analysis. Disasters in other regions affected some regional analysis. This seems to point to the relationships between the nations in question and key value chains that run through those regions. Europe for example is greatly affected by Asian disasters but the Caribbean and Sub-Saharan Africa analyses did not produce similar relationship.

Further study on the relationship between value chain disruptions and their impacts on national GDP may help to explain some of the dynamics uncovered here. The extent to which other nations rely on the North American consumer marketplace and/or the production basin in Asia, should help the quantify individual nations vulnerability to disasters. While the model suggests that disasters in these regions have far reaching impacts, all nations will not be affected similarly.

\section{REFERENCES}

Altay, N., \& Ramirez, A. (2010). Impacts of Disasters on Firms in Different Sectors: Implications for Supply Chains. Journal of Supply Chain Management, 46(4), 59-80.

Barnichon, R. (2009). The Optimal Level of Reserves for Low-Income Countries: Self-Insurance against External Shocks. IMF Staff Papers, 56(4).

Barrientos, A. (2010). Vulnerability and Social Protection in Small Island States: The Case of Grenada. Social and Economic Studies, 59, 3-30.

Burrus, R.T., Jr., Dumas, C.F., Farrell, C.H., \& Hall, W.W., Jr. (2002). Impact of low-intensity hurricanes on regional economic activity. Natural Hazard Review, 3(3), 118-25.

Charvériat, C. (2000). Natural Disasters in Latin America and the Caribbean: An Overview of Risk. InterAmerican Development Bank (IDB). Working Paper No 434.

Collymore, J. (2011). Disaster management in the Caribbean: Perspectives on institutional capacity reform and development. Environmental Hazards, 10, 6-22.

Dempsey, J.D. (2012, May/June). Consider Your Supply Chain Risk. The Corporate Board, pp. 21-25.

Dunford M., \& Smith, A. (2000). Catching Up or Falling Behind? Economic Performance and Regional Trajectories in the "New Europe". Economic Geography, 76(2), 169-195.

Dynes S., Johnson, M.E., Andrijcic, E., \& Horowitz, B. (2007). Economic costs of firm-level information infrastructure failures. The International Journal of Logistics Management, 18(3), 420-442.

Easter, C. (1999). Small States Development: A Commonwealth Vulnerability Index. The Round Table, $351,403-422$.

Ho Oh, E., Deshmukh, A., \& Hastak, M. (2010). Disaster impact analysis based on inter-relationship of critical infrastructure and associated industries: A winter flood disaster event. International Journal of Disaster, Resilience in the Built Environment, 1(1), 25-49.

Ewing, B.T., \& Kruse, J.B. (2002). The impact of project impact on the Wilmington, North Carolina, labor market. Public Finance Rev, 30(4), 296-309.

Ewing, B., Kruse, J., \& Thompson, M. (2010). Measuring the Regional Economic Response to Hurricane Katrina. CESifo Forum, 11, 80-85.

Frankfurt, A.M. (2009). Evidence from Hurricane Strikes in the Central American and Caribbean Region. Proceedings of the German Development Economics Conference, 35.

Greenberg, M.R., Lahr, M., \& Mantell, N. (2007). Understanding the Economic Costs and Benefits of Catastrophes and Their Aftermath: A Review and Suggestions for the U.S. Federal Government. Risk Analysis, 27(1), 83-96.

Gordon P., Moore J., Park J., \& Richardson H., (2010). Short-Run Economic Impacts of Hurricane Katrina (and Rita). CESifo Forum, 11, 73-79.

Guimaraes, P., Hefner, F.L., \& Woodward, D. (1993). Wealth and Income Effects of Natural Disasters: An Econometric Analysis of Hurricane Hugo. The Review of Regional Studies, 2, 97-114

Hager, M., Julca. A., \& Paddison. O. (2008). Analysing the Impact of Natural Hazards in Small Economies: The Caribbean Case. UNU/WIDER Research Paper 2008/25.

Hallegatte, S., \& Przyluski, V. (2010). The Economics of Natural Disasters. CESifo Forum, 11(2), 14-24. 
Henderson, L.J. (2004). Emergency and Disaster: Pervasive Risk and Public Bureaucracy in Developing Nations. Public Organization Review: A Global Journal, 4, 103-119.

Karim, A.J. (2011). Business Disaster Preparedness: An Empirical Study for measuring the Factors of Business Continuity to face Business Disaster. International Journal of Business and Social Science, 2(18), 183-192

Kellenberg, D.K., \& Mobarak, A.M. (2008). Does rising income increase or decrease damage risk from natural disasters? J. Urban Econ., 63(3), 788-802.

Kellenberg, D., \& Mobarak A.M. (2011, October). The Economics of Natural Disasters. Annual Review of Resource Economics, 3(1), 297-312.

Koks, E.E., \& Thissen, M. (2016). A multiregional impact assessment model for disaster analysis. Economic Systems Research, 28, 429-49.

Kreimer, A., \& Arnold, M. (2000). Managing Disaster Risk in - Emerging Economies. The World Bank, Disaster Risk Management Series, 2.

Lacho, K.J. (2008). The Impact of Hurricane Katrina on Small Business in Ruston, Louisiana. Academy of Strategic Management Journal, 7, 77-84.

Noy, I. (2008). The macroeconomic consequences of disasters. Journal of Development Economics, $88(2), 221-31$.

Perry, M. (2007). Natural disaster management planning: A study of logistics managers responding to the tsunami. International Journal of Physical Distribution \& Logistics Management, 37(5), 409433.

Panda, C., \& Narasimhan, V. (2007). Forecasting exchange rate better with artificial neural network. Journal of Policy Modeling, 29(2007), 227-236.

Rasmussen, T.N. (2004). Macroeconomic implications of natural disasters in the Caribbean. IMF Working Papers, No. WP/04/224, International Monetary Fund, Washington, DC.

Schipper, E.L.F., Cigarán, M.P., \& Hedger, M.M. (2008). Adaptation to climate change: The new challenge for development in the developing world. United Nations Development Programme (UNDP), New York, New York, USA.

Shaluf, I.M. (2007). An overview on disasters. Disaster Prevention and Management, 16(5), 687-703

Skidmore, M., \& Toya, H. (2002). Do Natural Disasters Promote Long-run Growth? Economic Inquiry, 40(3), 644-686

Surowiecki, J. (2011). Creative destruction? The New Yorker. Retrieved September 4, 2018.

Toya, H., \& Skidmore, M. (2007). Economic Development and the Impacts of Natural Disasters. Economics Letters, 94(1), 20-5.

Van der Veen, A. (2004). Disasters and Economic Damage: Macro, Meso and Micro Approaches. Disaster Prevention and Management, 13(4), 274-279. 


\section{APPENDIX: REGIONAL OUTPUTS OF THE STRUCTURAL EQUATION MODELING}

\section{European Results}

FIGURE 3

SCREEN SHOT OF THE OUTPUT FROM THE EUROPEAN MODEL

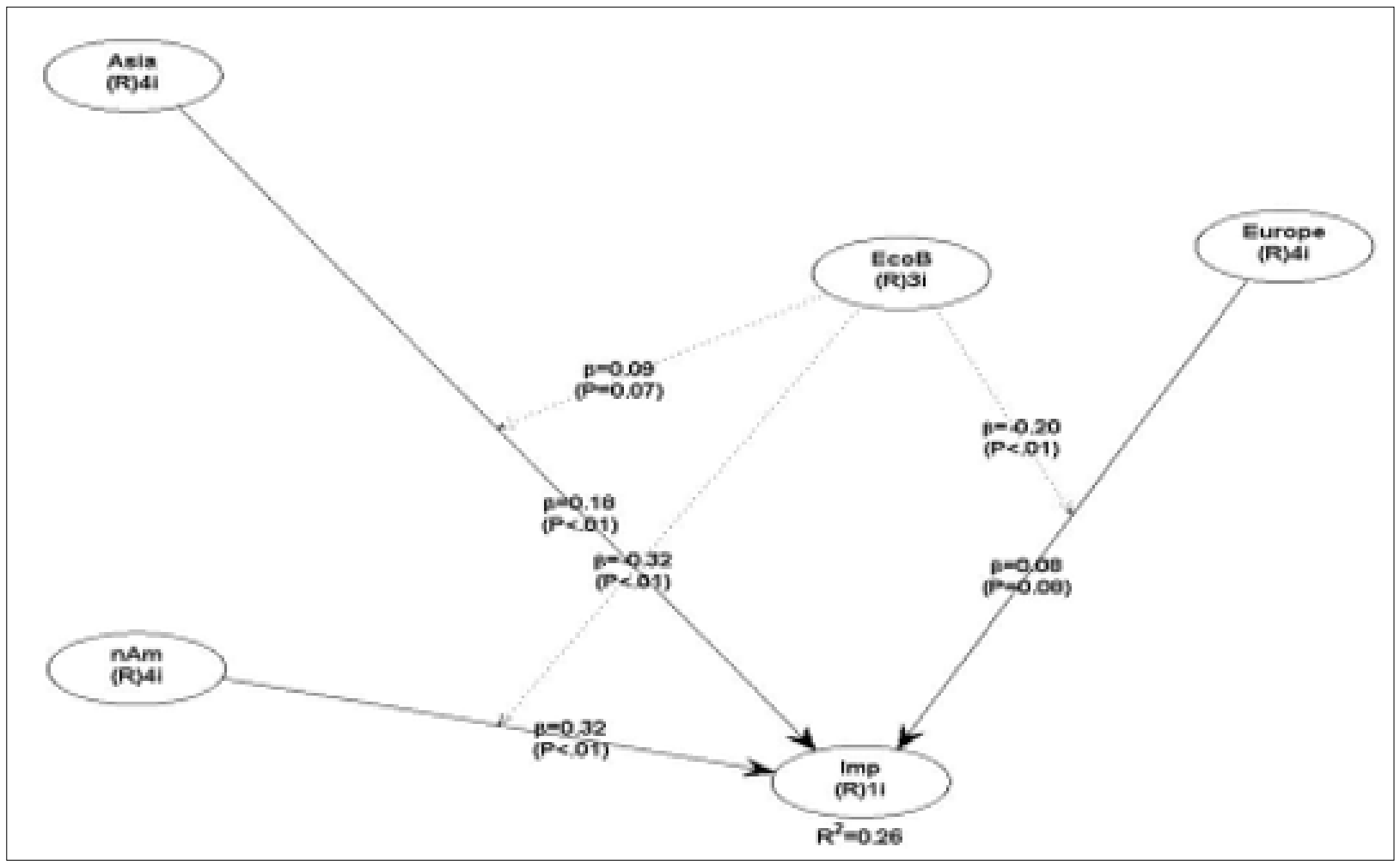

TABLE 6

SUMMARY OUTPUT FOR THE EUROPEAN ANALYSIS

\begin{tabular}{|l|l|}
\hline \multicolumn{1}{|c|}{ Model fit and quality indices } & \multicolumn{1}{c|}{ Acceptable Range } \\
\hline Average path coefficient (APC) $=0.196, \mathrm{P}<0.001$ & \\
\hline Average $\boldsymbol{R}$-squared $(\boldsymbol{A R S})=\mathbf{0 . 2 5 9}, \boldsymbol{P}<\mathbf{0 . 0 0 1}$ & \\
\hline Average adjusted R-squared (AARS) $=0.243, \mathrm{P}<0.001$ & acceptable if $<=5$, ideally $<=3.3$ \\
\hline Average block VIF (AVIF) $=1.157$, & acceptable if $<=5$, ideally $<=3.3$ \\
\hline Average full collinearity VIF (AFVIF) $=1.441$, & small $>=0.1$, medium $>=0.25$, large $>=$ \\
\hline & 0.36 \\
\hline Tenenhaus GoF (GoF) $=0.349$, & acceptable if $>=0.7$, ideally $=1$ \\
\hline Sympson's paradox ratio (SPR) $=0.833$, & acceptable if $>=0.9$, ideally $=1$ \\
\hline R-squared contribution ratio (RSCR) $=0.955$, & acceptable if $>=0.7$ \\
\hline Statistical suppression ratio (SSR) $=0.667$, & acceptable if $>=0.7$ \\
\hline $\begin{array}{l}\text { Nonlinear bivariate causality direction ratio } \\
\text { (NLBCDR) }=0.417\end{array}$ & \\
\hline
\end{tabular}




\section{Caribbean and Central America Results}

FIGURE 4

\section{CARIBBEAN AND CENTRAL AMERICA MODEL}

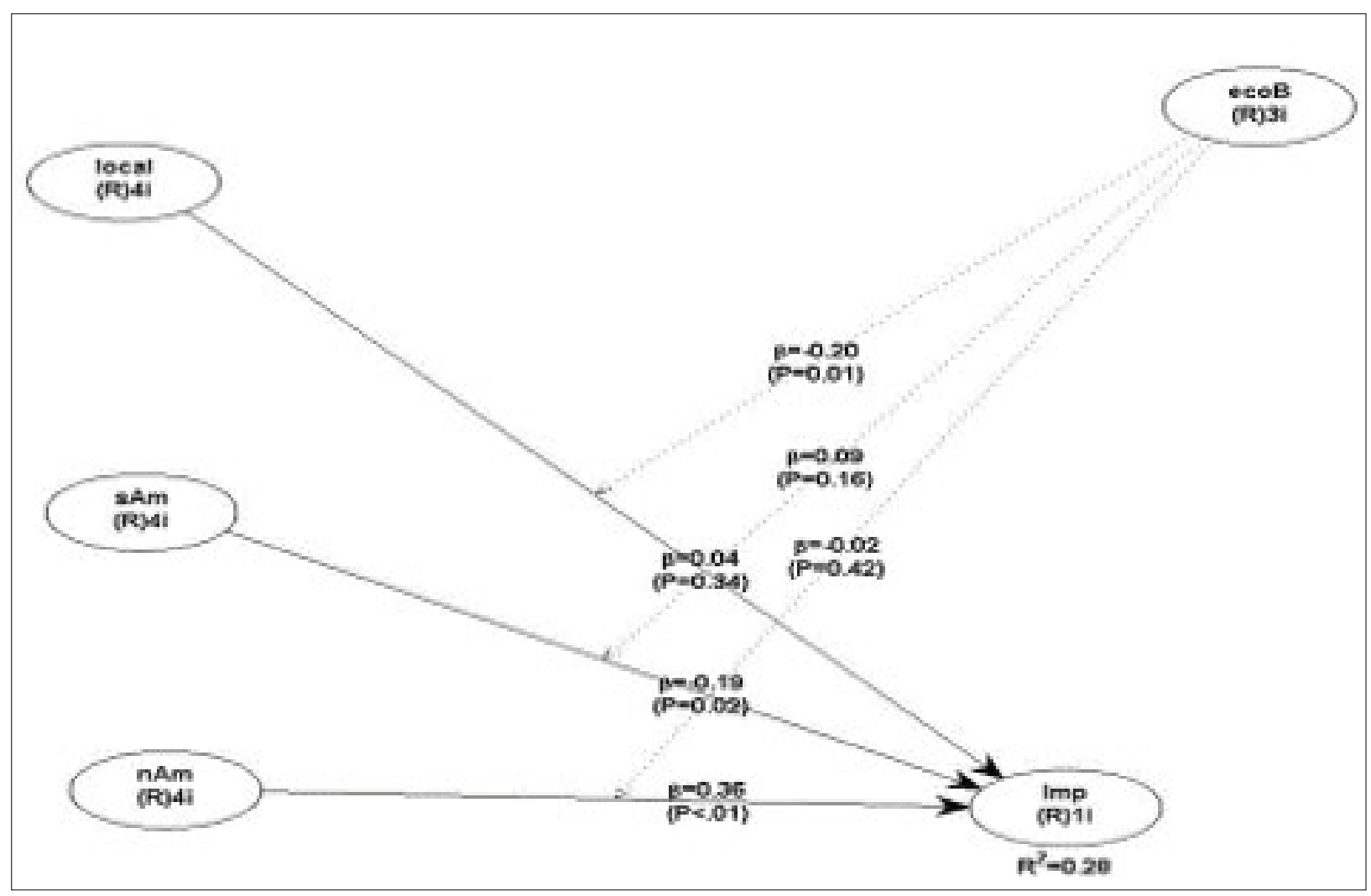

TABLE 7

SUMMARY OUTPUT FOR THE CARIBBEAN AND CENTRAL AMERICA ANALYSIS

\begin{tabular}{|l|l|}
\hline \multicolumn{1}{|c|}{ Model fit and quality indices } & \multicolumn{1}{c|}{ Acceptable Range } \\
\hline Average path coefficient (APC) $=0.149, \mathrm{P}=0.022$ & \\
\hline Average $\boldsymbol{R}$-squared $(\boldsymbol{A R S})=\mathbf{0 . 2 8 1}, \boldsymbol{P}<\mathbf{0 . 0 0 1}$ & \\
\hline Average adjusted R-squared (AARS) $=0.244, \mathrm{P}<0.001$ & acceptable if $<=5$, ideally $<=3.3$ \\
\hline Average block VIF (AVIF) $=1.240$ & acceptable if $<=5$, ideally $<=3.3$ \\
\hline Average full collinearity VIF (AFVIF) $=1.851$ & small $>=0.1$, medium $>=0.25$, large $>=$ \\
\hline & 0.36 \\
\hline Tenenhaus GoF (GoF) $=0.383$ & acceptable if $>=0.7$, ideally $=1$ \\
\hline Sympson's paradox ratio (SPR) $=0.833$ & acceptable if $>=0.9$, ideally $=1$ \\
\hline R-squared contribution ratio (RSCR) $=0.992$ & acceptable if $>=0.7$ \\
\hline Statistical suppression ratio (SSR) $=1.000$ & acceptable if $>=0.7$ \\
\hline Nonlinear bivariate causality direction ratio & \\
(NLBCDR) $=0.833$ &
\end{tabular}




\section{Asian Results}

FIGURE 5

OUTPUT FROM THE ASIAN MODEL

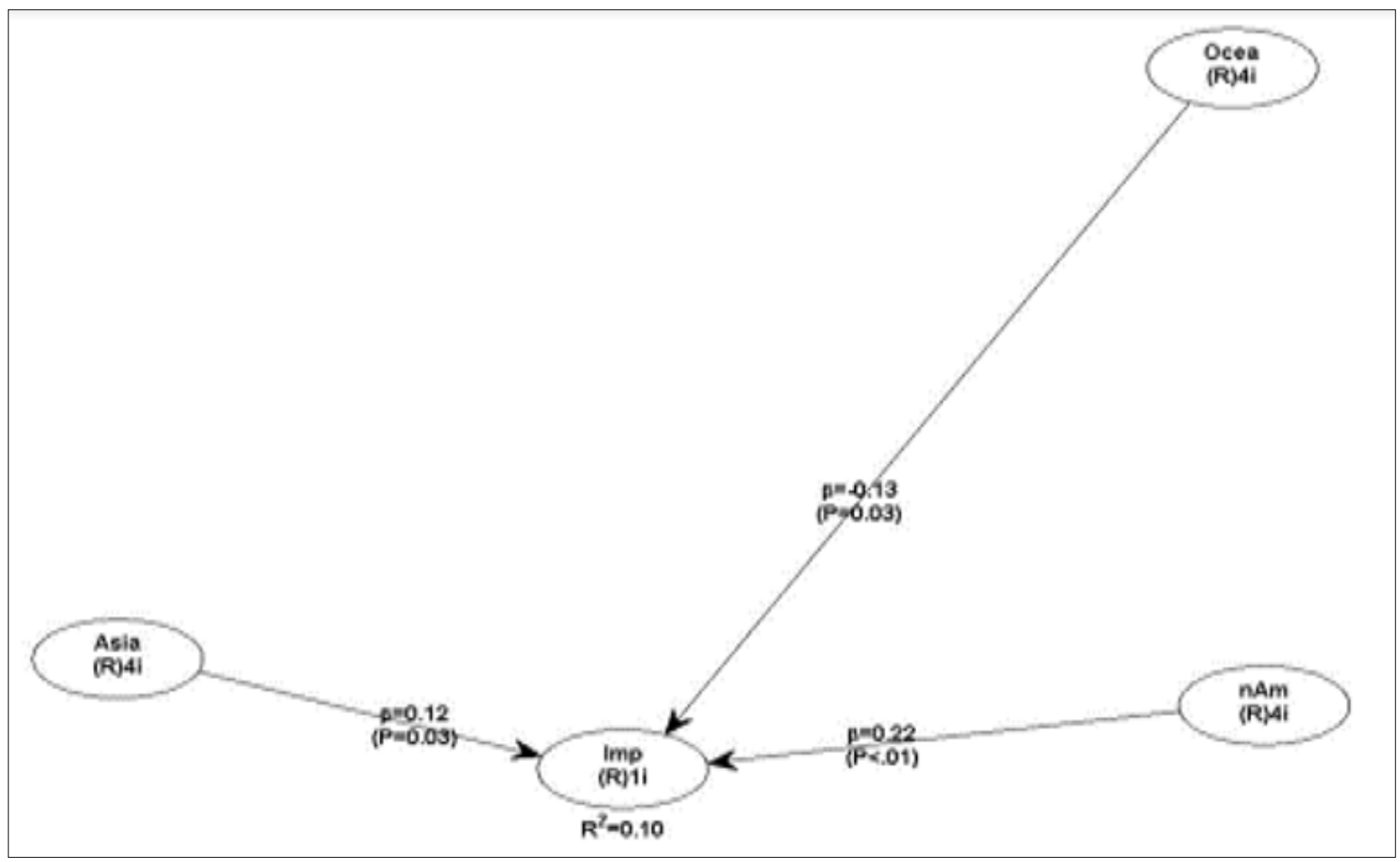

TABLE 8

SUMMARY OUTPUT FOR THE ASIAN ANALYSIS

\begin{tabular}{|l|l|}
\hline \multicolumn{1}{|c|}{ Model fit and quality indices } & \multicolumn{1}{c|}{ Acceptable Range } \\
\hline Average path coefficient $(\mathrm{APC})=0.158, \mathrm{P}=0.004$ & \\
\hline Average $\boldsymbol{R}$-squared $(\boldsymbol{A R S})=\mathbf{0 . 1 0 2}, \boldsymbol{P}=\mathbf{0 . 0 3 0}$ & \\
\hline Average adjusted R-squared (AARS) $=0.089, \mathrm{P}=0.043$ & acceptable if $<=5$, ideally $<=3.3$ \\
\hline Average block VIF (AVIF) $=1.060$ & acceptable if $<=5$, ideally $<=3.3$ \\
\hline Average full collinearity VIF (AFVIF) $=1.042$ & small $>=0.1$, medium $>=0.25$, large $>=$ \\
\hline & 0.36 \\
\hline Tenenhaus GoF (GoF) $=0.242$, & acceptable if $>=0.7$, ideally $=1$ \\
\hline Sympson's paradox ratio (SPR) $=1.000$ & acceptable if $>=0.9$, ideally $=1$ \\
\hline R-squared contribution ratio (RSCR) $=1.000$ & acceptable if $>=0.7$ \\
\hline Statistical suppression ratio (SSR) $=1.000$ & acceptable if $>=0.7$ \\
\hline Nonlinear bivariate causality direction ratio & \\
(NLBCDR) $=0.833$ &
\end{tabular}




\section{Sub-Saharan African Results}

FIGURE 6

OUTPUT FROM THE SUB-SAHARAN AFRICAN MODEL.

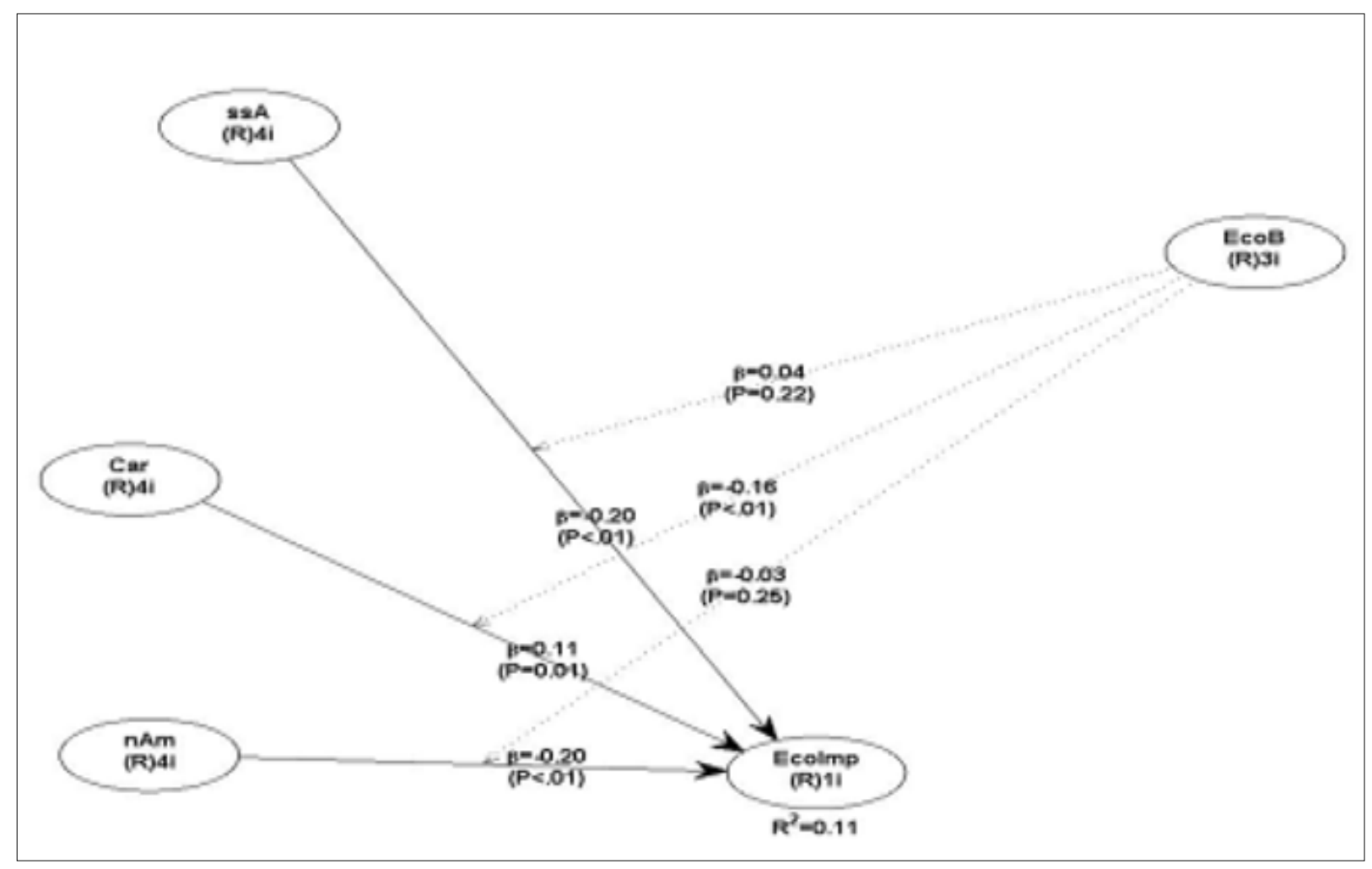

TABLE 9

SUMMARY OUTPUT FOR THE SUB-SAHARAN AFRICAN ANALYSIS

\begin{tabular}{|l|l|}
\hline \multicolumn{1}{|c|}{ Model fit and quality indices } & \multicolumn{1}{c|}{ Acceptable Range } \\
\hline Average path coefficient (APC) $=0.124, \mathrm{P}=0.003$ & \\
\hline Average $\boldsymbol{R}$-squared $(\boldsymbol{A R S})=\mathbf{0 . 1 1 0}, \boldsymbol{P}=\mathbf{0 . 0 0 7}$ & \\
\hline Average adjusted R-squared (AARS) $=0.096, \mathrm{P}=0.014$ & acceptable if $<=5$, ideally $<=3.3$ \\
\hline Average block VIF (AVIF) $=1.143$ & acceptable if $<=5$, ideally $<=3.3$ \\
\hline Average full collinearity VIF (AFVIF) $=1.029$ & small $>=0.1$, medium $>=0.25$, large $>=$ \\
\hline & 0.36 \\
\hline Tenenhaus GoF (GoF) $=0.225$ & acceptable if $>=0.7$, ideally $=1$ \\
\hline Sympson's paradox ratio (SPR) $=1.000$ & acceptable if $>=0.9$, ideally $=1$ \\
\hline R-squared contribution ratio (RSCR) $=1.000$ & acceptable if $>=0.7$ \\
\hline Statistical suppression ratio (SSR) $=0.833$ & \\
\hline Nonlinear bivariate causality direction ratio & acceptable if $>=0.7$ \\
(NLBCDR) $=0.833$ &
\end{tabular}

